\title{
HYPOBARIC HYPOXIA-RELATED IMPAIRMENT OF PULMONARY SURFACTANT PROTEINS A AND D DID NOT faVOUR PNEUMOCYSTIS CARINII FRENKEL 1999 GROWTH IN NON-IMMUNOCOMPROMISED RATS
}

\author{
VIVES M.F.*, CASPAR-BAUGUIL S.**, ALIOUAT E.M.***, ESCAMILLA R.****, PERRET B.*, DEI-CAS E.***** \\ \& PRÉVOST M.C.*
}

\section{Summary:}

It has been suggested that patients with pulmonary surfactant impairment are more susceptible to Pneumocystis infection than healthy controls. Owing the fact that most patients with pulmonary surfactant impairment also suffer from hypoxia, we explored the effect of intermittent hypobaric hypoxia conditions on the ability of non-immunocompromised rats infected by endotracheal route with $P$. carinii to clear the infection from their lungs. Control rats, inoculated or not with $P$. carinii, were maintained in normobaric normoxic conditions, and were submitted or not to dexamethasone administration. It was found that even if hypobaric hypoxia weakened host immune mechanisms and impaired significantly the surfactant composition, mainly of surfactant proteins A and D, these changes were not enough to favour the Pneumocystis growth or to inhibit the clearing of Pneumocystis organisms from the lungs of non-immunocompromised rats. The potential influence of surfactant protein changes on Pneumocystis infection is discussed.

KEY WORDS : Pneumocystis, pneumonia, pulmonary surfactant, rat, altitude, hypobaric hypoxia.
Résumé : Des altérations des PROtÉINES A et D DU SURFACTANT PULMONAIRE INDUITES PAR HYPOXIE HYPOBARE N'ONT PAS FAVORISÉ LE DÉveloppement de PNEUMOCYSTIS CARINII FrenKel 1999 CHEZ LE RAT NON-IMMUNOCOMPROMIS

Il a été suggéré que les patients avec un surfactant pulmonaire altéré sont plus susceptibles à Pneumocystis que les individus avec un surfactant normal. Comme la plupart des patients avec des altérations du surfactant présentent une hypoxie associée, nous avons exploré l'effet de conditions d'hypoxie hypobare intermittente sur la capacité de rats non-immunocompromis infectés avec Pneumocystis carinii par voie endo-trachéale, à éliminer leur infection. Les rats témoins, inoculés ou pas avec P. carinii, ont été maintenus dans des conditions de pression atmosphérique et d'oxygénation normales et traités ou pas par la dexaméthasone. Ces expériences ont montré que même si les conditions d'hypoxie hypobare altèrent significativement la composition du surfactant, notamment le niveaux de protéines $A$ et $D$, et affectent les effecteurs de la réponse immune, elles ne facilitent pas la croissance de P. carinii ni inhibent les mécanismes d'élimination des parasites des poumons des rats non-immunocompromis. L'influence potentielle des changements des protéines du surfactant sur l'infection par Pneumocystis, est discutée.

MOTS CLÉS : Pneumocystis, pneumonie, surfactant, rat, altitude, hypoxie hypobare.

al., 2001). However, asymptomatic colonization or sub-clinical $P$. jirovecii infection has been reported in apparently immunocompetent subjects or in patients with slight immunodepression but with lung disorders such as chronic obstructive pulmonary disease (COPD) (Cano et al., 1993; Calderon et al., 1996; Miller et al., 2001). Consistently, recent experimental research has shown that Pneumocystis organisms are able to replicate in the lung of immunocompetent hosts (Chabé et al., 2004) keeping intact their pathogenic power, as attested by the fact that Pneumocystis cells were able to infect susceptible hosts by airborne route in which they induced Pneumocystis pneumonia (PcP) (Dumoulin et al., 2000; Gigliotti et al., 2003; Chabé et al., 2004). Thus, though immunocompetent hosts are usually able to radically eliminate the parasites from their lungs (Sepkowitz et al., 1993), as long as they remain infected they are able to transmit the infection either to naive healthy hosts, which will develop a primary infection, or to immunosuppressed hosts, which may then develop PcP. In this manner, healthy hosts could behave 
as a dynamic reservoir to Pneumocystis species (DeiCas, 2000; Chabé et al., 2004).

Interestingly, oxygen is a regulator of pulmonary surfactant protein gene expression, especially in the lungs of animals exposed to hyperoxia (Nogee et al., 1991). Little information is available however on the effect of hypoxic conditions on either the pulmonary surfactant composition (Nardo et al., 2005) or the Pneumocystis development in the pulmonary alveolus. Synthesized by type II pneumocytes, pulmonary surfactant is a complex of protein (10 \%) and lipid (90 \%) molecules, which accumulates at the air/water interface and lowers the surface tension to prevent alveolar collapse (Dobbs et al., 1982; Robertson et al., 1992). Four specific surfactant-associated proteins (SPs) have been identified: hydrophilic proteins, SP$\mathrm{A}$ and SP-D; and hydrophobic proteins, SP-B and SPC (Possmayer, 1988; Ingenito et al., 1999; Haagsman \& Diemel, 2001).

It is difficult to define the specific role of each surfactant protein because their respective effects tend to overlap one another. Nevertheless, it is commonly admitted that both SP-B and SP-C greatly increase the adsorption of surfactant lipids onto the surface film that lines the alveolus (Perez-Gil \& Keough, 1998; Whitsett \& Weaver, 2002). SP-C is the smallest (4.2-8 kDa) and the most hydrophobic surfactant protein (with $70 \%$ of hydrophobic amino acids), and is only found in the lungs (Glasser et al., 2001). SP-B is an 8.7-kDa-protein component of tubular myelin, and enhances adsorption and re-spreading (Whitsett et al., 1995; Oviedo et al., 2001). SP-B is required for normal lung function (Melton et al., 2003; Nesslein et al., 2005).

SP-A and SP-D belong to the collectin family and they play a role in the innate immunity of the lung via their ability to bind various pathogens (Crouch \& Wright, 2001; Wright, 2005). SP-A was the first surfactant protein to be identified, and is also the most abundant (Ingenito et al., 1999). Its molecular mass varies from 26 to $38 \mathrm{kDa}$. This protein also facilitates surface-active properties of the surfactant in the alveolus and regulates in vitro surfactant phospholipids synthesis (Kubchandani et al., 2001; Palaniyar et al., 2001). SP-D is a $43 \mathrm{kDa}$ protein that has sequence homology to SP-A (Crouch, 2000); it is also involved in immune functions and participates to surfactant homeostasis (Crouch \& Wright, 2001).

There are contrasting reports on the effect of hypobaric hypoxia on immune functions. Early work showed that exposure to hypoxia resulted in increased immunoglobulin levels with concomitant resistance to viral infection (Trapani, 1966). Chohan et al. (1975) reported increased serum IgG and IgA levels both in high-altitude natives and in sea-level natives inducted to high altitudes compared to sea-level residents. In contrast, Mirrakhimov \& Kitaev (1979) and Kitaev \& Tokhta- bayev (1981) reported increased infant mortality due to respiratory infections among high-altitude natives. Meehan (1987) has shown that hypoxic exposure makes experimental animals more susceptible to bacterial infections. The latter observations suggest that the host defence mechanisms might be impaired under hypobaric hypoxia conditions. Nevertheless, cellular effectors of the immunity are particularly sensitive to oxidant stress because of the high content of polyunsaturated fatty acids in their plasma membranes (Coquette et al., 1986; Meydani et al., 1995). Moreover, these cells produce relatively high amounts of reactive oxygen intermediates as normal part of their specific defensive role. SaiRam et al. (1998) showed that hypoxia enhanced macrophage free radical production and induced an oxidative stress (decreased blood level of reduced glutathione and increased plasma malondialdehyde levels), leading to decreased T-cell activity.

In a previous study (Prévost et al., 1980), we demonstrated changes in surfactant phospholipids of rats exposed to hypobaric hypoxia. Furthermore, we have observed that in HIV infected patients, pulmonary surfactant abnormalities were present before PcP onset (Escamilla et al., 1992, 1993; Prevost et al., 1998). Likewise, in healthy young rabbits that develop currently benign PcP at weaning (Rajagopalan et al., 1998; DeiCas et al., 2006) marked surfactant changes occur before the development of PcP (Aliouat et al., 1998). We therefore hypothesized that surfactant modifications, especially of protein content, could promote Pneumocystis proliferation in the alveolar space of non-immunosuppressed hosts. The purpose of the present study was therefore to evaluate the influence of intermittent hypobaric hypoxia induced changes of pulmonary surfactant composition on the ability of $P$. carinii Frenkel 1999 to grow in the lungs of nonimmunocompromised laboratory rats.

\section{MATERIALS AND METHODS}

\section{ANIMAL MODEL, ALTITUDE SIMULATOR CHAMBER AND EXPERIMENTAL DESIGN}

W eaned male Wistar rats (Janvier, Le Genest St Isle, France) weighing $87.4 \pm 4.6 \mathrm{~g}$, were randomly divided in six groups, each one submitted to a specific condition. Group-1 rats (six rats) received dexamethasone in drinking water $(2 \mathrm{~g} / \mathrm{L})$ three weeks before $P$. carinii inoculation and for the entire duration of the experiment. This group was used as control of the infectious power of the used $P$. carinii isolate. Rats of group 2 (six rats) were placed for four hours in an altitude simulator chamber designed by one of us (M.C.P, INSERM U563). In this system, atmospheric pressure can be decreased to $370 \mathrm{~mm} \mathrm{Hg}$ 
(corresponding to 6,000-m altitude) or increased to $760 \mathrm{~mm} \mathrm{Hg}$ (sea level atmospheric pressure) in $20 \mathrm{~min}$. There is not alteration of relative proportions of diverse gases that compose the atmospheric air. It results therefore a decrease of partial $\mathrm{O}_{2}$ pressure from about $160 \mathrm{~mm} \mathrm{Hg}$ at the sea level to about $78 \mathrm{~mm} \mathrm{Hg}$ inside the chamber. The airflow rate inside the simulator was $420 \mathrm{~L} / \mathrm{h}$, corresponding to three renewals per hour of simulator atmosphere. The decrease of air pressure as well as the return to normobaric normoxic condition occurred at a rate of $17 \mathrm{~mm} \mathrm{Hg} / \mathrm{min}$. After the 4-hour exposure, when pressure reached $760 \mathrm{~mm} \mathrm{Hg}$, group-2 rats were euthanatized. They were used as a control of the effect of hypobaric system on pulmonary surfactant in absence of $P$. carinii.

Rats of groups 3, 4 and 5 (six rats per group) were inoculated with $P$. carinii by intratracheal route (see below) and placed in the altitude simulator chamber for 4-hours/day sequential exposures five days/week for one, two or three weeks, respectively, and then euthanatized. Group-6 rats (six animals) were also inoculated with $P$. carinii but they were not exposed to hypobaric hypoxia (control group).

\section{SOURCE OF P. CARINII \\ AND INTRATRACHEAL INOCULATION}

The rats of all groups, except of group 2, were infected by non-surgical endotracheal route with $P$. carinii organisms (Ambrose et al., 2004) obtained from corticosteroid-treated Wistar rats (Dei-Cas et al., 1998). Parasite extraction from tissue lung and purification were performed as previously (Aliouat et al., 1993). These methods revealed efficient in obtaining viable and infectious P. carinii organisms (Anonyme, 1996; DurandJoly et al., 2002). Uninfected control rats of group 2 were handled before $P$. carinii infected ones in order to avoid accidental airborne contamination, even in the altitude-simulating chamber, and were housed in a different room. Food and water were given ad libitum. Body weight and food uptake were recorded one and three times per week, respectively. The experimental protocol was approved by the local INSERM ethical scientific committee, according to the ethical principles laid down by the French Ministry of Agriculture. MCP holds the personal licence number 31-64 ("Certificat d'Autorisation d'expérimenter sur Animaux - Décret No 87-848 du 19 octobre 1987") establishing the authorisation to develop animal experimentations.

\section{ASSESSING RESPIRATORY FUNCTION}

Breath frequency was measured in wide-awake unrestrained rats before and after hypobaric-hypoxia exposure using a plethysmograph, Datanalyst ${ }^{\circ}$ and Iox ${ }^{\circ}$ software's for in vivo data acquisition and real time analysis (AC 264, Emka Technologies, Paris, France). Arterial blood was taken on anesthetized rats $(45 \mathrm{mg} / \mathrm{kg}$ Ketamin hydrochloride - Rhone Mérieux, Lyon, France) two days before hypobaric hypoxia exposure and immediately after. Femoral arterial blood sample was taken as soon as rats were returned to normobaric normoxic conditions. Blood gas analysis ( $\mathrm{PaO} 2, \mathrm{PaCO} 2, \mathrm{Hb}-$ saturation), blood $\mathrm{pH}$ and acid-base balance assessing were performed within $10 \mathrm{~min}$ following the experiment on ABL-500 apparatus with specific electrodes (Radiometer, France).

\section{ASSESSING THE IMMUNOLOGICAL FUNCTION}

At the time of euthanasia, two samples of heparinized blood were obtained from rat abdominal venous and used to assess cellular content and to isolate lymphocytes for flow cytometric analysis. Samples were treated with ACK buffer (Barten et al., 2001) (10 $\mathrm{min}$ at room temperature) to eliminate red blood cells, and incubated with anti-TCRaß-FITC $($ TCR $=$ T cell receptor $)(1 / 100)$, antiCD4-biotine/streptavidine (1/400), or anti-B-lymphocytePE 1/200) antibody to label cells by immunofluorescence as previously described (Barten et al., 2001).

The influence of hypobaric hypoxia conditions on the susceptibility of peripheral lymphocytes to oxidative stress was evaluated by using the kit "Radicaux Libres" (KRL test, "Spiral" laboratories, Couternon, France), which was developed by Purpan-Hospital Biochemical Department (Toulouse, France) and previously applied to erythrocytes (Stocker et al., 2003; Lesgards et al., 2005). Briefly, the test assesses the capacity of cells to resist to lysis after a challenge with standardized oxidative radical source. Leukocytes were separated by centrifugation (20 min, $400 \mathrm{~g}$ ) over lymphocyte separation medium (Eurobio, Les Ulis, France) from heparinized venous blood of rats diluted 1:2 in saline. Contaminating red blood cells were lysed with ammonium chloride lytic buffer. After washing, leukocytes were counted on Coulter T540 (Beckman/coulter), distributed in 96-well microplates and exposed, at $37^{\circ} \mathrm{C}$, to the standardized release of free radicals resulting from the thermal decomposition of a $27-\mathrm{mmol} / \mathrm{L} 2,2$ 'azo-bis (2-amidinopropane) dihydrochloride solution (Stocker et al., 2003; Lesgards et al., 2005). Cell lysis rate was then assessed by measuring the optical density decay at $620 \mathrm{~nm}$. Half slope mean is the time (minutes) when $50 \%$ lysis occurs. Several experiments were made exposing each time six $P$. carini $i$-infected rats to hypobaric hypoxic conditions.

\section{Collection OF LUNG TISSUE SAMPLES}

Lung tissue samples were divided in three parts. One part was used for $P$. carinii detection and quantification (see below). A second part was immediately snapfrozen (in liquid nitrogen) and stored in deep freezer $\left(-80^{\circ} \mathrm{C}\right)$ until RNA extraction. The last part was used for protein quantification and analysis. 


\section{P. CARINII DETECTION AND QUANTIFICATION}

Pneumocystis detection and quantification in lung tissue was performed on air-dried lung homogenate smears stained with RAL 555 (RAL, France). The total number of cystic forms (intermediate or late sporocytes and cysts) was calculated as previously described (Aliouat et al., 1993; Anonyme, 1996; Durand-Joly et al., 2002).

\section{ISOLATION OF MRNA \\ AND NORTHERN BLOT ANALYSIS}

Total mRNA was isolated from 100-mg frozen lung tissue samples with Trizol method according to the manufacturer's instructions (Invitrogen, France). Precipitated mRNA was dissolved in sterile $\mathrm{H}_{2} \mathrm{O}$, quantified by absorbance at $260 \mathrm{~nm}$ and stored at $-80^{\circ} \mathrm{C}$ until analysis. Ten $\mu \mathrm{g}$ of mRNA from each sample was separated on formaldehyde gel, and capillary transferred on a nitrocellulose membrane.

SP-A, SP-B, SP-C and SP-D complementary DNA probes were made by transcription-polymerase chain reaction (RT-PCR) from RNA extracted from adult rat lung. The specific primers used were as follows: (a) for SP-A (557 bp), 299-CCT GGA GGA CGT GGA GAC AAG-320 and 856-TGC AGG GTT TTA CAG ACC AGA TG-833; (b) for SP-B (462 bp), 280-AAG TTC CTG GAA CAA GAA TGT GA-303 and 742-CCC AGC AGT GCA TCT AGT AGA AG-719; (c) for SP-C (377 bp), 178-ATG GGC CTT CAC ATG AGT CAG-199 and 555-TCT CCA CAC AAG GTG CTC ACA-534; for SP-D (498 bp), 639ACA GAG GTG CTC CTG GAG ACA-660 and 1137-CTA GGG GCT CAG AAC TCA CAG A-1115.

The "AlkPhos Direct Labelling and Detection System" from Amersham Biosciences involves direct labelling of cDNA probe with a thermo-stable alkaline phosphatase enzyme by a covalently cross-linker, according to manufacturer instructions. For detection step, we used CDP-Star chemiluminescent reagent (Amersham Biosciences, France). A scanner and Image Quant software (Amersham Biosciences, France) were used to quantify mRNA band. Hybridization was also performed on the 18S rRNA to assess potential loading error on the reactive mRNA band.

\section{PROTEIN EXTRACTION AND WESTERN BLOT ANALYSIS OF SURFACTANT PROTEINS}

Rapidly, frozen lung tissue samples were thawed in ice cold RIPA buffer containing PMSF, Aprotin, Leuptin, then disrupted with an ultra-thurax and homogenized with a Dounce homogenizer at $4{ }^{\circ} \mathrm{C}$. Extracted proteins were quantified by Bradford micro dosage (Bradford, 1976). $50 \mu \mathrm{g}$ proteins were separated on acrylamide gels. The reticulation of gels was function of protein molecular weight: $12 \%$ for SP-A and SP-D and $16 \%$ for SP-B and SP-C. We carried out electrophoresis in glycine buffer for SP-A and SP-D, and in tricine buffer for SP-B and SP-C (Biorad, France). Then we proceed to transfer (nitrocellulose for SP-A, SP-D and PVDF for SP-B, SP-C) in semi-dry electro blotting apparatus.

Proteins were detected after blotting with antibodies directed against SP-A and SP-D (Santa Cruz Biotechnology, France) and against pro-proteins SP-B and SP-C (Chemicon International, France, and Santa Cruz biotechnology France). A goat (Jackson Immuno Research laboratories inc., France) or rabbit (Promega, France) horseradish peroxidase (HRP) conjugated was used as secondary antibody. For detection, we used Chemiluminescence Luminol Reagent according to supplier protocol (Amersham Biosciences, France). Each blotting membrane was normalized by analysis with a monoclonal anti- $\beta$-actin antibody (Sigma, France). A scanner and Image Quant software (Amersham Biosciences, France) were used to assess the density of protein bands in relation to actin band density (Fig. 6). Uninfected non-immunocompromised rats maintained in normobaric normoxic conditions were used as source of control or normal surfactant samples.

\section{STATISTICAL ANALYSIS}

When appropriate, data were presented as mean \pm SEM. In statistical comparisons $t$ Student test was used and $p<0.05$ was considered as the limit of statistical significance.

\section{RESULTS}

\section{CHARACTERIZING THE EXPERIMENTAL MODEL}

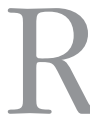
at weight decreased significantly by $9.9 \%$ (p < $0.017)$ after one-week, by $13 \%(\mathrm{p}<0.0027)$ after two weeks, and by $12 \%(\mathrm{p}<0.016)$ after three weeks of intermittent hypobaric hypoxia (Fig. 1). Under our experimental conditions, rats exposed to hypobaric hypoxia ate $13 \%$ to $27 \%$ less than controls. Weight decrease could also result from an increased elimination of body water secondary to both changes in vapour pressure inside the chamber and enhanced urine flow (Guiol et al., 1986).

Rats in the simulator chamber had impaired ventilation with a significant increase in respiratory rate (Table I). Analysis of arterial blood gases showed severe hypoxemia with a mean $\mathrm{PaO}_{2}$ of $32.4 \mathrm{~mm} \mathrm{Hg}$ after a 4-hour exposure. The high $\mathrm{PaCO}_{2}$ values in control - as in experimental rats (Table I) could be related to the fact that animals were anaesthetized at the time of blood collection. The increase in haemoglobin level could be due rather to hemo-concentration than to hypoxemia. Actually, micro-haematocrit was found to be increased in animals exposed to hypobaric hypoxia conditions (data not shown). 
4-h exposure

to hypobaric hypoxia

$(n=6)$

$\begin{aligned} & 144.2 \pm 4.9^{*} \\ & 7.35 \pm 0.004 \\ & 32.4 \pm 0.7^{*} \\ & 46.6 \pm 1.05 \\ & 38.0 \pm 7.5^{*} \\ & 15.5 \pm 0.5 \\ & 24.9 \pm 0.4 \\ & \text { ND }\end{aligned}$

1-week exposure to hypobaric hypoxia $(n=6)$

$146.2 \pm 17.8^{*}$

$7.33 \pm 0.1$

$64.8 \pm 19.6$

$43.7 \pm 2.5$

$76.4 \pm 20.0$

$15.3 \pm 0.2$

$22.4 \pm 1.8$

$0.30 \pm 0.2$

${ }^{a}$ Results are shown as mean \pm SEM of six different animals. Measures were performed in triplicate separated by intervals of two min. The mean of three measures was considered as the basal value for one given animal.

${ }^{\mathrm{b}}$ Breath frequency was measured in wide-awake unrestrained rats.

"Arterial blood was taken on anesthetized rats (see "Material and methods" section).

d Pneumocystis cyst counts per animal performed three weeks p.i.. Negative counts (microscopically undetectable parasites) were not included. Animals of this control group were inoculated with $P$. carinii and housed under normobaric normoxic conditions.

$\mathrm{Hb}=$ hemoglobin; $\mathrm{PaO}_{2}$ and $\mathrm{PaCO}_{2}=$ Partial $\mathrm{O}_{2}$ and $\mathrm{CO}_{2}$ pressures, respectively; $\mathrm{SaO}_{2}=\mathrm{O}_{2}$-hemoglobin saturation; $\mathrm{HCO}_{3}{ }^{-}=$bicarbonate level in blood; $\mathrm{ND}=$ not done.

* Significant difference.

Table I. - Non-immunocompromised Wistar rats: hypobaric hypoxia impact on respiratory function and on the number of Pneumocystis carinii organisms in lungs ${ }^{\mathrm{a}}$.

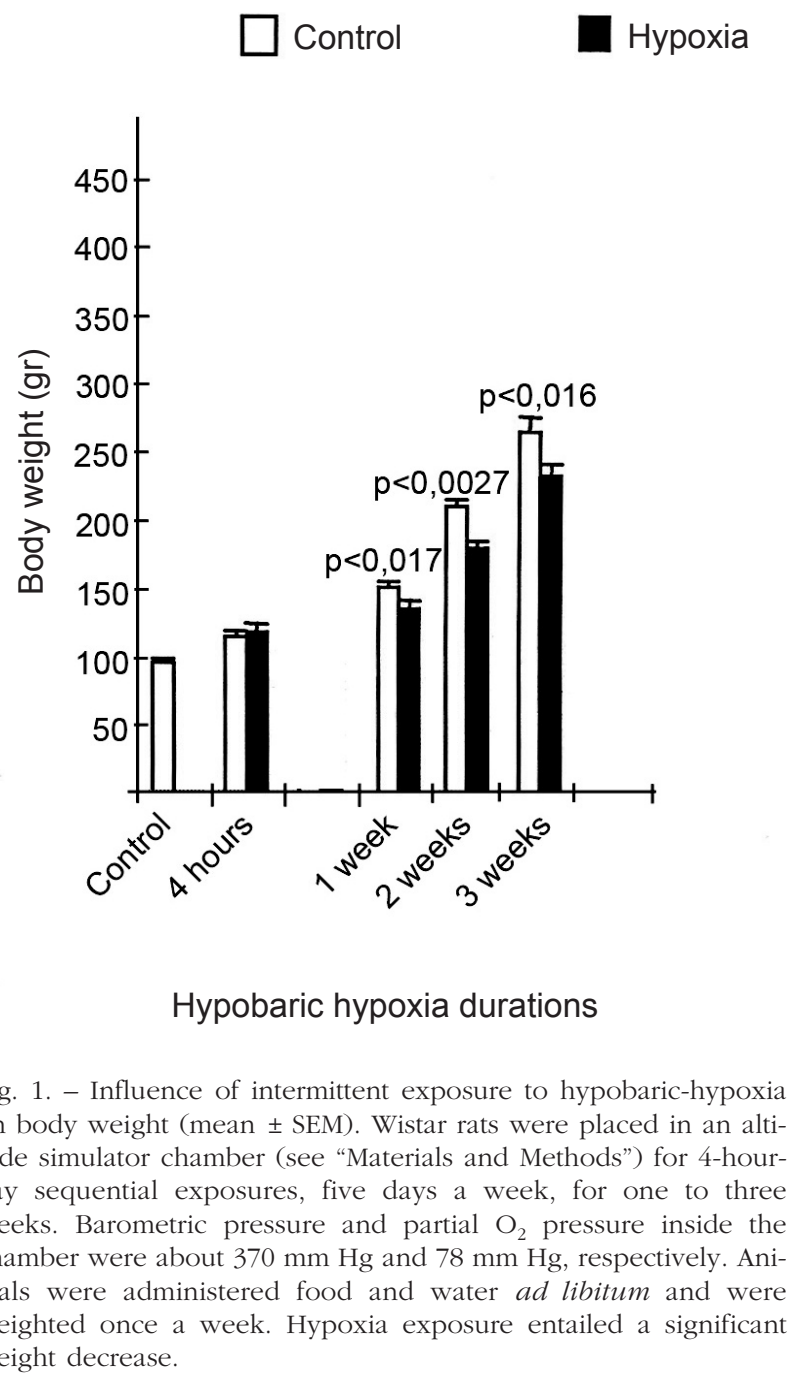

\section{INFLUENCE OF HYPOBARIC HYPOXIA ON $P$. CARINII INFECTION}

$P$. carinii growth was assessed at the same intervals in rats exposed to hypobaric hypoxia and in dexamethasone-treated rats housed under normobaric normoxic conditions. As expected, dexamethasone-treated rats developed $\mathrm{PcP}$ with parasite rates of $8.8 \pm 1.610^{5}$ $P$. carinii cysts per animal one-week post-inoculation (p.i.) and $2.2 \pm 0.710^{6}$ cysts per animal three weeks p.i. (Fig. 2).

Three weeks p.i., neither group- 6 control rats nor rats exposed to hypobaric hypoxia conditions had cleared all their parasites from their lungs. At the end of the experiment parasite counts ranged from microscopically undetectable rates to $10^{4}$ cystic forms per animal in either hypobaric-hypoxia exposed $\left(6 \pm 3 \quad 10^{4}\right)$ or unexposed rats $\left(9 \pm 110^{4}\right)$. In our work conditions, hypobaric hypoxia condition did not influence therefore significantly the ability of presumably immunocompetent rats to eliminate Pneumocystis organisms from their lungs.

\section{EFFECT OF HYPOBARIC HYPOXIA ON RAT PERIPHERAL BLOOD LYMPHOCYTES}

Data from rats exposed to hypobaric hypoxia conditions (groups 3-5) were compared with both dexamethasone-treated rats (group 1) and unexposed control animals (group 6) just before Pneumocystis inoculation (Fig. 3). In hypoxemic rats, the number of total lymphocytes was unchanged (Fig. 3A). Cell distribution analysis evaluated as percentage of total lymphocytes showed a significant decrease in B lymphocytes $(\mathrm{p}=$ 


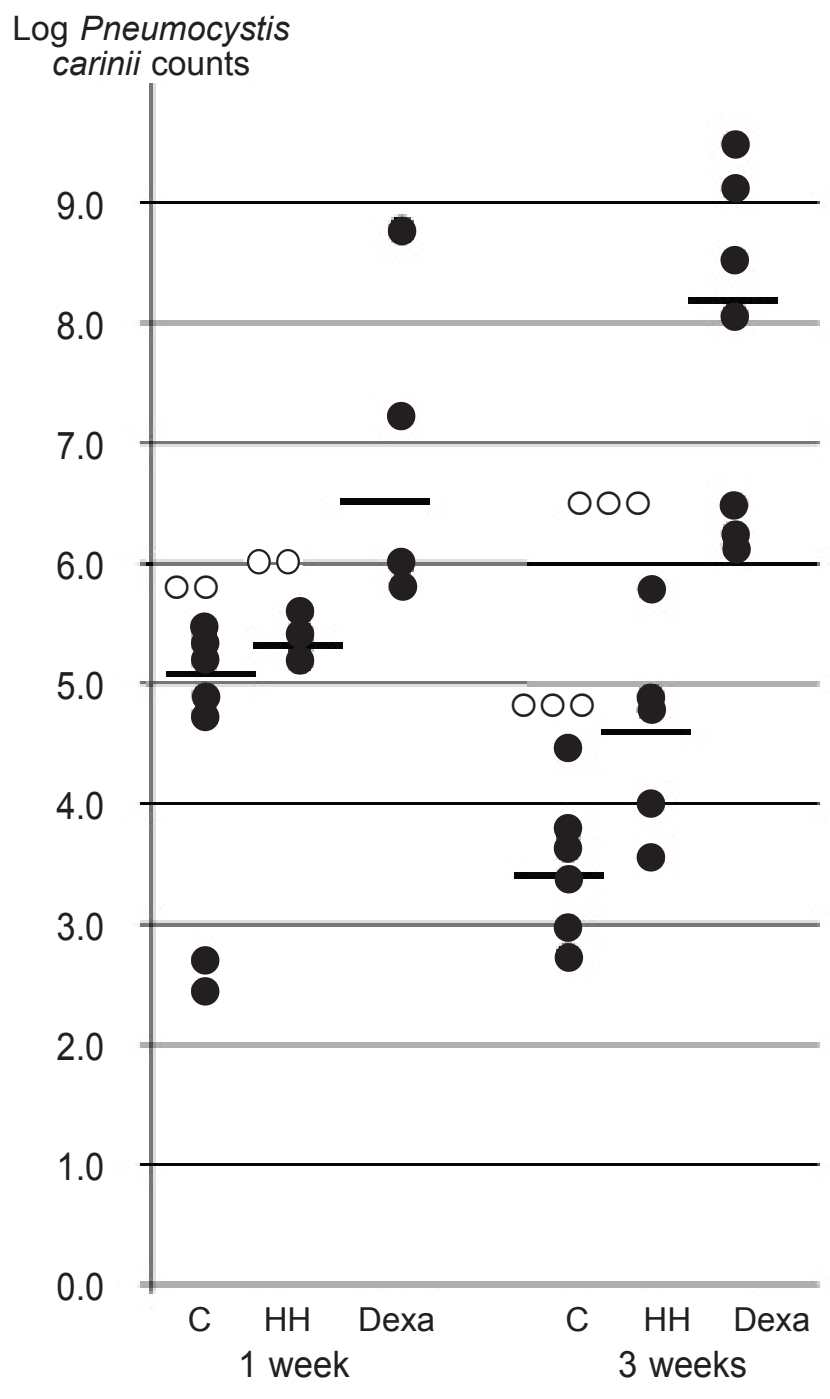

Fig. 2. - Influence of intermittent exposure to hypobaric-hypoxia on Pneumocystis carinii rates. Rats were placed in an altitude simulator chamber as indicated in figure 1 caption. The animals were exposed to hypobaric-hypoxia for one week or for three weeks. Each solid circle corresponds to one animal. Horizontal traits represent the average rates. C: control rats endotracheally inoculated with infectious $P$. carinii organisms and maintained in normobaric normoxic conditions; $\mathrm{HH}$ : rats endotracheally inoculated with infectious $P$. carinii organisms and exposed to hypobaric-hypoxia conditions; Dexa: dexamethasone-treated rats (see text) endotracheally inoculated with infectious $P$. carinii organisms and maintained in normobaric normoxic conditions. Open circles indicate statistically significant differences: ${ }^{\circ}: \mathrm{p}<0.05 ;{ }^{\circ}: \mathrm{p}<0.005 ;{ }^{\circ 00}: \mathrm{p}<0.0001$.

0.001, Fig. 2B) and an increase of $\mathrm{CD}^{+} \mathrm{T}$ lymphocytes (Fig. 3C and D).

KRL test was used to evaluate the susceptibility to oxidative stress of lymphocytes from $P$. carinii-infected rats exposed to hypobaric hypoxia compared to those of control rats of group $6(P$. carinii-infected and maintained under normobaric normoxic conditions) (Fig. 4). Half slope mean $(n=6)$ was $53.5 \pm 2.0$ min for lymphocytes of hypobaric hypoxia exposed rats, and $75.4 \pm$ 5.1 min for lymphocytes of control rats $(n=6)$, res- pectively. Peripheral lymphocyte resistance to oxidative cytolysis was thus lowered significantly (17\%) in rats exposed to hypobaric hypoxia.

\section{EFFECT OF HYPOBARIC HYPOXIA ON PULMONARY SURFACTANT PROTEIN COMPOSITION}

SP-C and SP-D mRNAs were not sensitive to hypobaric hypoxia. In contrast, a 33 \%-decrease in SP-B mRNA was recorded after a 4-h-exposure to hypoxia (Fig. 5). However, after 2-3-weeks intermittent exposure to hypoxia, SP-B mRNA tended to return to the level recorded in group-6 control rats. On the contrary, SP-A mRNA decreased regularly and significantly (even compared to 4-h-hypoxic rats) all along the intermittent exposure to hypoxia. Lowest SP-A mRNA amounts were recorded after a two-week exposure to hypobaric hypoxia (Fig. 5).

In order to determine whether decreased amounts of surfactant protein mRNAs were associated with actual protein amount changes, a Western blot analysis of the four surfactant proteins was performed (Fig. 6). Banddensitometry analysis indicated that both hydrophobic protein precursors decreased after 4-h-exposure to hypoxia ( $55 \%$ for SP-B and $70 \%$ for SP-C). After one to three weeks of 4-h intermittent hypoxia, all the surfactant proteins decreased of almost $45 \%$ (Fig. 6). SP-C protein increased significantly compared to its level after a 4-h hypoxia exposure (Fig. 6).

Intratracheal inoculation of $P$. carinii organisms did not influence surfactant-protein amounts in corticosteroiduntreated rats exposed or not to hypobaric hypoxia (Fig. 7). As expected, corticosteroid administration enhanced the synthesis of pulmonary surfactant components. Consistently, SP-A and SP-B were found to be significantly increased (Fisher et al., 1991) (Fig. 7).

\section{DISCUSSION}

The used altitude simulator chamber works in diminishing the barometric pressure from $760 \mathrm{~mm} \mathrm{Hg}$ (normobaric normoxic conditions) to $370 \mathrm{~mm} \mathrm{Hg}$. As in these experiments relative proportions of $\mathrm{O}_{2}, \mathrm{CO}_{2}$ and $\mathrm{N}_{2}$ were not changed, it can be deduced that $\mathrm{O}_{2}$ partial pressure inside the chamber fallen from about $160 \mathrm{~mm} \mathrm{Hg}$ (at sea level) to about $78 \mathrm{~mm} \mathrm{Hg}$. This change has evident physiological impact as biochemical and physiological action of a given gas is depending on the pressure it is exerting.

Several studies showed that alveolar epithelial cells tolerate hypoxia remarkably well and are able to maintain oxidative phosphorylation down to very low oxygen concentrations (Jain \& Sznajder, 2005). Little is known however about the consequences of hypoxia on pulmonary surfactant. 

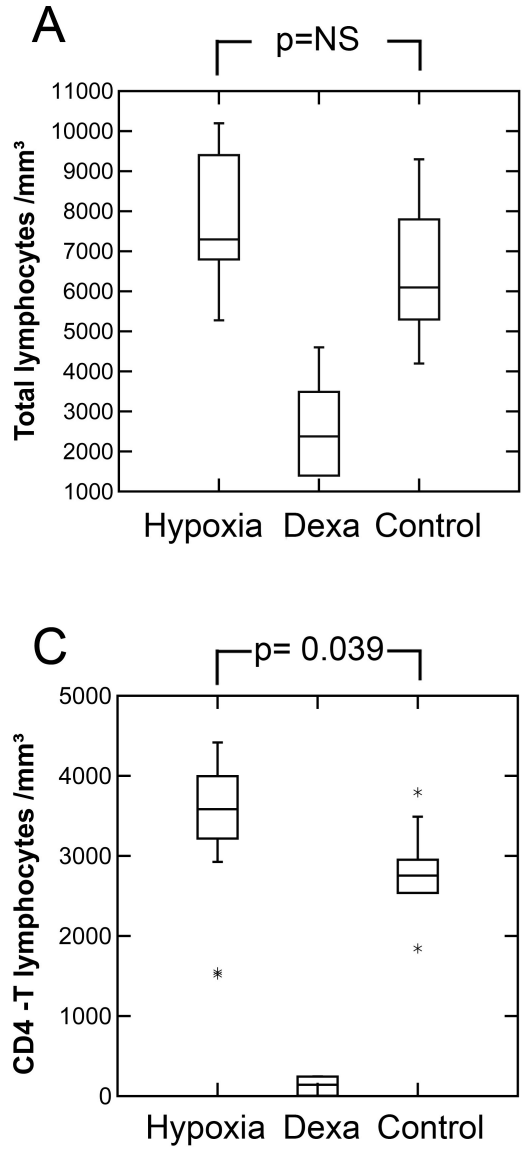
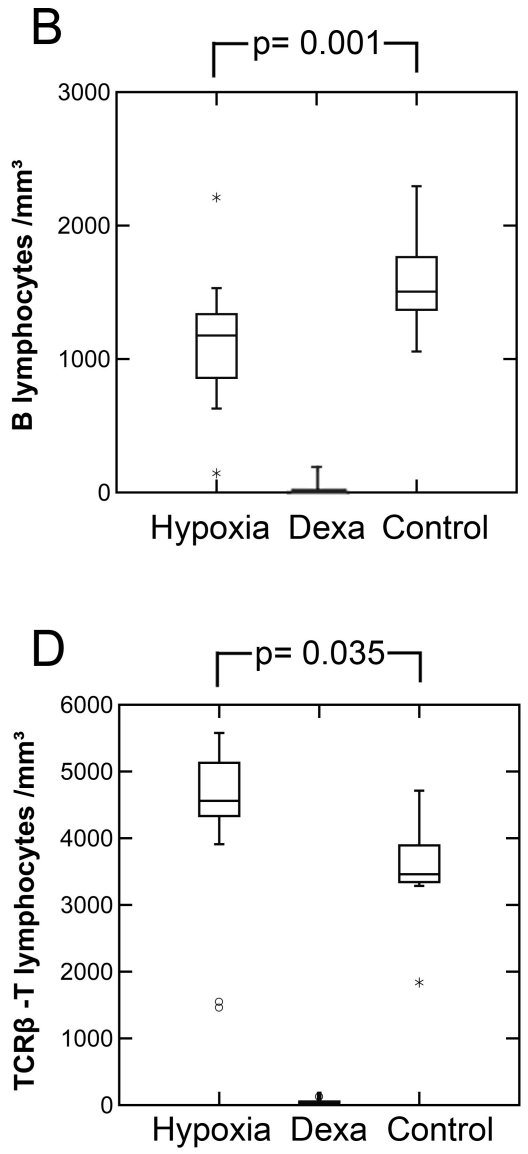

Fig. 3. - Influence of intermittent exposure to hypobaric-hypoxia on peripheral blood lymphocytes assessed by flow cytometry (mean \pm SEM). Pneumocystis-carinii endotracheally inoculated Wistar rats placed in an altitude simulator chamber as indicated in figure 1 caption. Three groups were compared: animals exposed for three weeks to intermittent hypobaric hypoxia ("Hypoxia"), and dexamethasonetreated ("Dexa") or untreated rats ("Control") maintained in normobaric normoxic conditions. Dexamethasone administration induced both marked decrease of total, B- or T lymphocytes (A-D). In rats of dexamethasone-untreated groups, total lymphocyte counts were apparently not influenced by hypobaric hypoxia (A). In contrast, a significant decrease in B lymphocytes (B) and a small increase of $\mathrm{CD}^{+}$ $\mathrm{T}$ lymphocytes $(\mathrm{C}$ and $\mathrm{D})$ were recorded in rats exposed to hypobaric hypoxia.
In previous studies it was reported that hypoxia decreased surfactant protein in preterm infants and in ovine foetuses (Nardo et al., 2005; Gortner et al.,

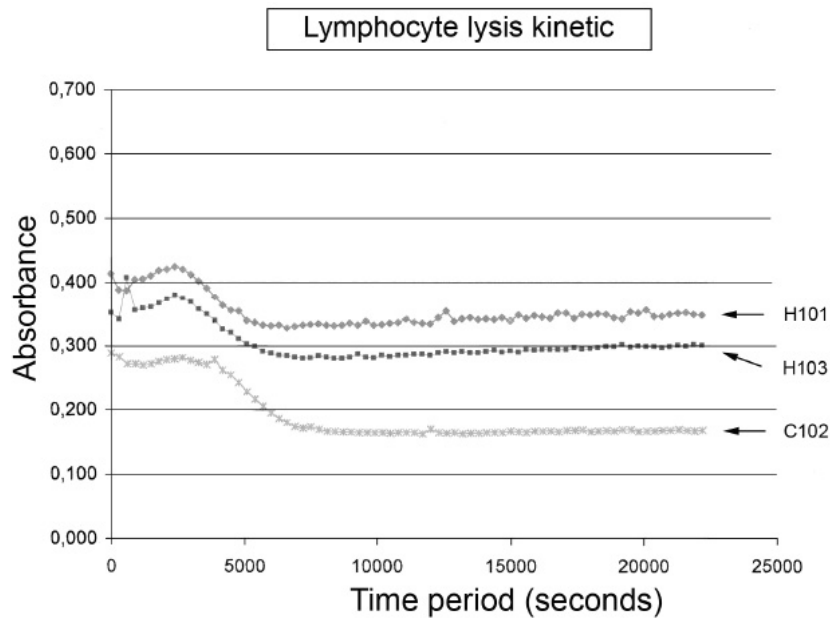

Fig. 4. - Influence of hypobaric-hypoxic conditions (animals placed in an altitude simulator chamber as explained in figure 1 caption) on the susceptibility of rat peripheral blood lymphocytes to oxidative stress (KRL test, see "Materials and Methods"). Control or experimental Wistar rats were endotracheally inoculated with $P$. carinii organisms (see text). Lymphocyte cell lysis was assessed by measuring absorbance. Results of a representative experiment. Lymphocytes of two rats (H101, H103) exposed for four hours to hypobaric hypoxia, and of one control rat (C102) maintained in normobaric normoxic conditions.
2005). Our study is the first, however, that reports a decrease of all surfactant proteins in adult rats exposed to intermittent hypobaric hypoxia. Thus, in our work conditions, a decrease of the two surfactant hydrophobic proteins was recorded. SP-B-decrease was about $55 \%$ after 4-hour exposure, and $50 \%$ after intermittent long-lasting hypoxia (Fig. 6). The mRNA data suggest that SP-B decreasing could be controlled at a posttranscriptional level. Hydrophobic proteins are critical to life. Especially, decreasing of SP-B has likely a marked impact on the respiratory function (Tokieda et al., 1999; Walther et al., 2002). Interestingly, in the mouse, Pneumocystis growth induced a decrease of hydrophobic SP-B and SP-C. This effect could increase surface tension and contribute thus to hypoxemia (Beers et al., 1999; Atochina et al., 2000). With regard to SP-C, the lowest concentration was observed after a 4-hhypoxia exposure (Fig. 6). In rats exposed to longer hypoxia periods, SP-C levels tended to come near the control level, this trend resulting likely from an adaptive physiological response. As SP-C mRNA level remained stable, SP-C decrease and subsequent increase during hypoxia could result from processes occurring at a post-transcriptional level. SP-C was shown to participate to innate immunity as it can bind lipid A moiety of LPS in a specific and competitive fashion (Augusto et al., 2001, 2002). This interaction prevents the acti- 

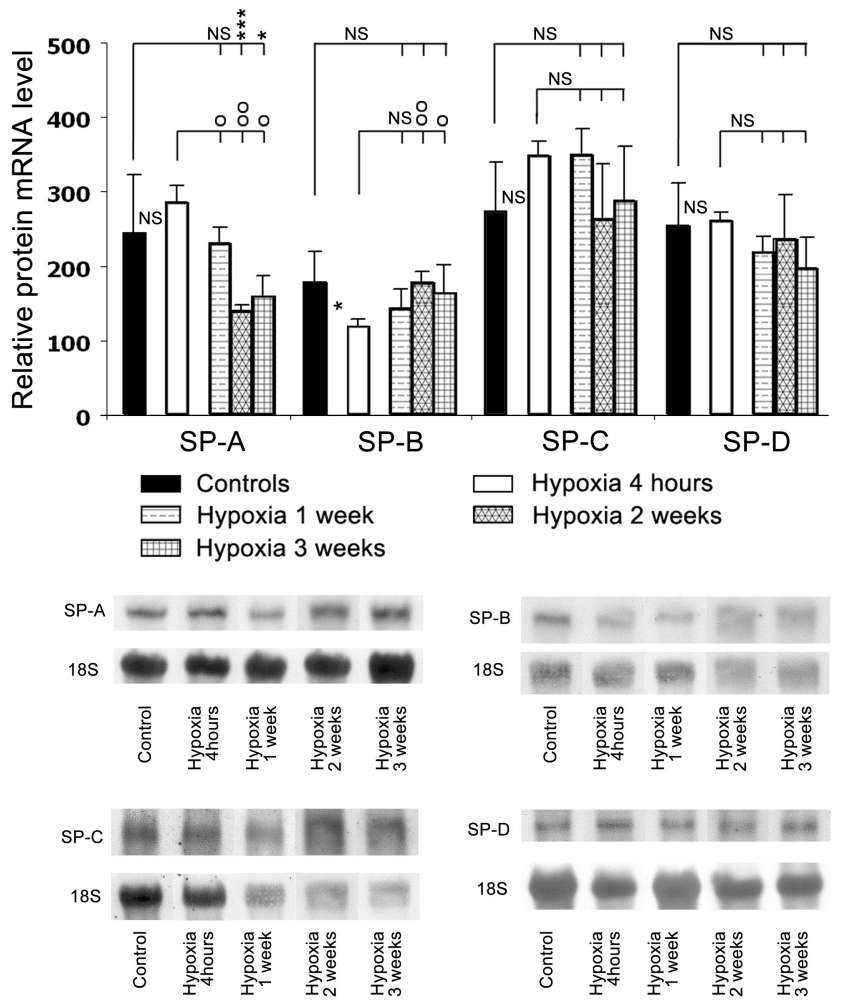

Fig. 5. - Influence of intermittent exposure to hypobaric-hypoxia in an altitude simulator chamber (as indicated in figure 1 caption) on the expression of pulmonary surfactant protein mRNA. Control or experimental rats were endotracheally inoculated with $P$. carinii organisms (see text). Northern hybridization with complementary DNA probes followed by mRNA band quantification (see "Materials and Methods") showed the relative levels of SP-A, SP-B, SP-C and SP-D mRNAs in P. carinii endotracheally inoculated rats exposed or unexposed (controls) to intermittent hypobaric hypoxia. The sizes of the transcript were as follows: $1.6 \mathrm{~kb}$ (SP-A), $1.5 \mathrm{~kb}$ (SP-B), $0.8 \mathrm{~kb}$ $(\mathrm{SP}-\mathrm{C})$ and $1.3 \mathrm{~kb}(\mathrm{SP}-\mathrm{D})$, respectively. Significant differences compared respectively to controls $(*)$ or to 4 -hour hypoxia rats $\left(^{\circ}\right)$ are shown. ${ }^{*}$ or ${ }^{\circ}$ if $\mathrm{p}<0.05$, by ${ }^{* *}$ or ${ }^{\circ}$ if $\mathrm{p}<0.005$ and by ${ }^{* * * *}$ or ${ }^{\circ} \circ$ if $\mathrm{p}<0.0001$ (Student $t$ test); NS $=$ no significant.

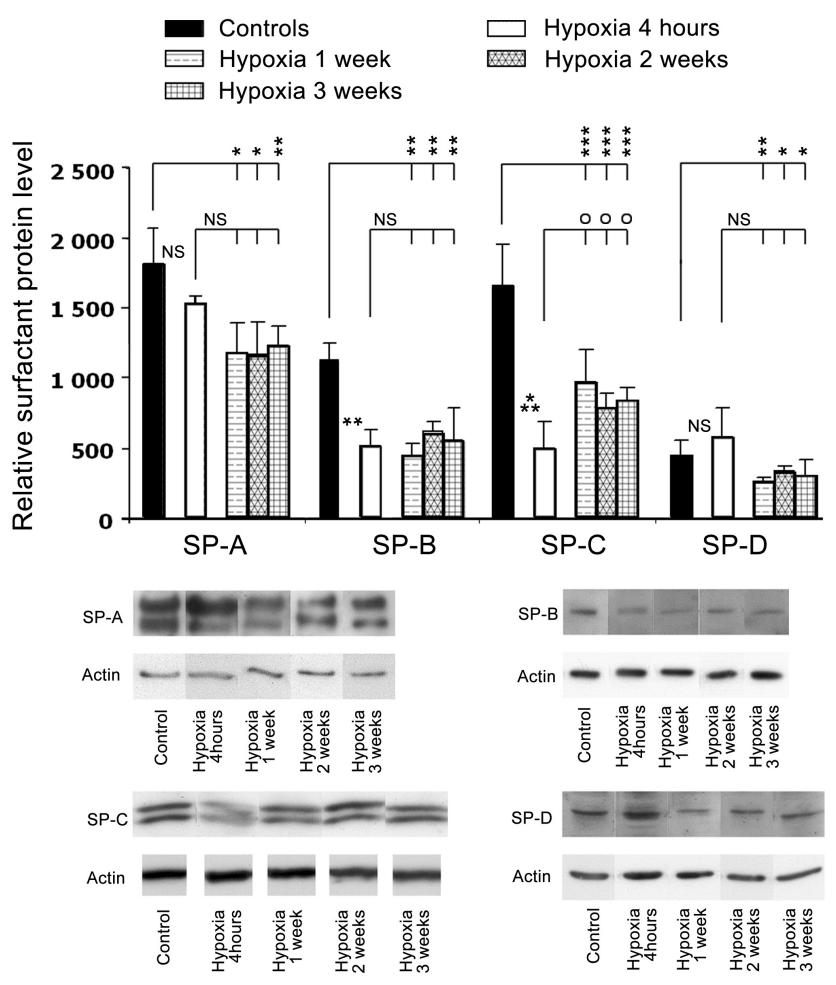

Fig. 6. - Influence of intermittent exposure to hypobaric-hypoxia in an altitude simulator chamber (as indicated in figure 1 caption) on pulmonary surfactant protein production. Control or experimental rats were endotracheally inoculated with $P$. carinii organisms (see text). Anti-SP-A antibody labelled strongly two bands of $32 \mathrm{kDa}$ and $36 \mathrm{kDa}$ glycosylated proteins. Specific antibody against SP-B recognized a $25-\mathrm{kDa}$ pro-protein. Anti-SP-C antibody labelled two specific bands corresponding to $21 \mathrm{kDa}$ pro-protein and $24 \mathrm{kDa}$ palmitoylated pro-protein, respectively. Anti-SP-D antibody recognized one specific band at $43 \mathrm{kDa}$. Results were normalized after betaactin hybridization (see text). Significant differences compared respectively to controls $\left(^{*}\right)$ or to four hour hypoxia rats $\left(^{\circ}\right)$ are shown by * or $^{\circ}$ if $\mathrm{p}<0.05$, by ${ }^{* *}$ or ${ }^{\circ}$ if $\mathrm{p}<0.005$ and by ${ }^{* * *}$ or ${ }^{\circ 00}$ if $\mathrm{p}<$ 0.0001 (Student $t$ test); NS $=$ no significant.
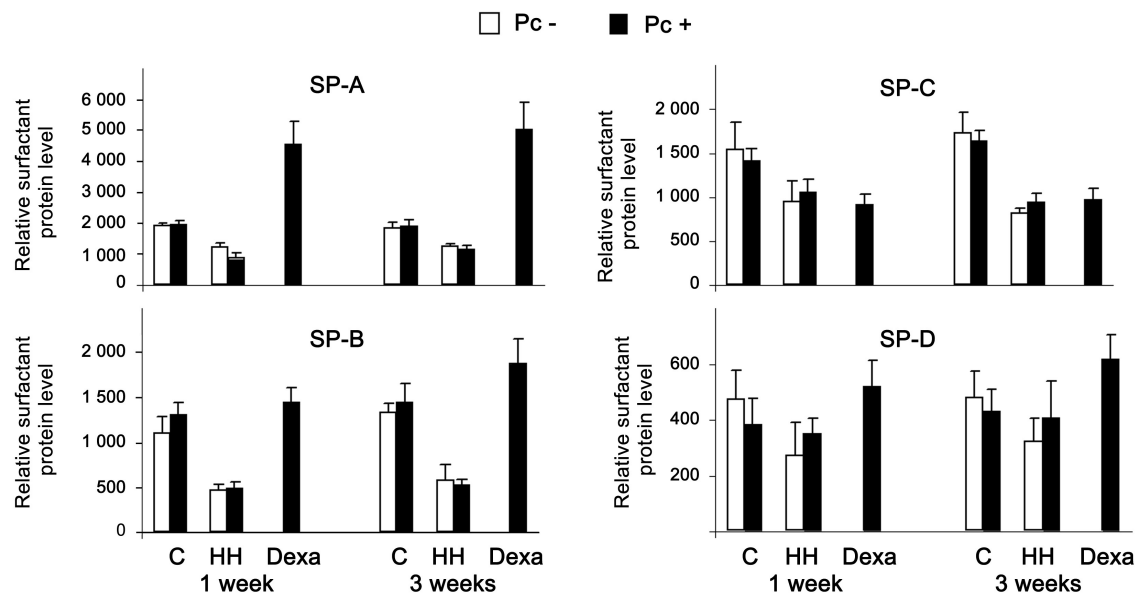

Fig. 7. - Influence of Pneumocystis carinii infection on the surfactant protein rates in immunocompetent Wistar rats exposed to hypobaric-hypoxia in an altitude simulator chamber (as indicated in figure 1 caption). P. carinitinfected $\left(\mathrm{PC}^{+}\right)$or uninfected $\left(\mathrm{PC}^{-}\right)$rats of the control groups (C) were maintained in normobaric normoxic conditions. $P$. carinii-infected or uninfected rats of the group $\mathrm{HH}$ were exposed to hypobaric hypoxia conditions. The "Dexa" group is constituted by dexamethasone-treated Wistar rats that were endotracheally infected with $P$. carinii and maintained in normobaric normoxic conditions. Dexa group attested that the used $P$. carinii organisms were infectious. In these experiments, the endotracheal inoculation of $P$. carinii organisms did not influence surfactant-protein amounts in immunocompetent rats exposed or not to hypobaric hypoxia. 
vation of macrophage CD14 receptor by LPS and consequently prevents the pro-inflammatory response due to this cytokine and to NO release (Beers et al., 2005).

Hypobaric hypoxia conditions induced also a significant decrease in the lung content of SP-A (Figs. 5 and 6) and SP-D (Fig. 6). SP-D protein decrease after intermittent hypobaric hypoxia was about $33 \%$ (compared to control) (Fig. 6) and it was apparently not related to mRNA changes (Fig. 5). Inflammatory changes usually associated to hypoxia (Hirche et al., 2004) could affect SP-D concentration as this protein is susceptible to specific degradation by Neutrophil Serine Proteinase. Compared with control animals maintained in normobaric normoxic conditions (Fig. 6), the expression of collectin SP-A, which possesses immuno-regulatory properties and modulates lung inflammatory responses, was also affected by hypobaric hypoxia as reported previously (Facco et al., 2005).

Reduction of SP-A after intermittent hypobaric hypoxia could result from the inflammatory process in alveoli. Actually, mediators of the pulmonary inflammatory response could be responsible for surfactant decreasing. Consistently, TNF- $\alpha$ (Tumor necrosis factor-alpha) has been shown to reduce SP-A mRNA and protein level in lung epithelial cells and in NCI-H441 cells (Pryhuber et al., 1998; Miakotina et al., 2002). Actually, two factors could be involved in the down regulation of surfactant proteins: TNF- $\alpha$ and TGF- $\beta$ (Transforming growth factorbeta) (Pryhuber et al., 1998; Dhainaut et al., 2003). In rats, hypoxia induced lung inflammation as early as two hours after exposure, with an over-expression of proinflammatory cytokines such as TNF- $\alpha$ (Madjdpour et al. 2003). Moreover, TGF- $\beta$ factor seems also to be increased in hypoxic conditions (Dhainaut et al., 2003). Anyway, neither hypoxic conditions, as attested by $\mathrm{PaO}_{2}$ values $(32.4 \pm 0.7 \mathrm{~mm} \mathrm{Hg}$ after 4-hour hypoxia, and $64.8 \pm 19.6 \mathrm{~mm} \mathrm{Hg}$ after intermittent hypoxia exposure, compared to $\mathrm{PaO}_{2}=99.1 \pm 6,8 \mathrm{~mm} \mathrm{Hg}$ in unexposed group-6 control rats) (Table I), nor pulmonary surfactant protein impairment (Figs 5-7), and potentially associated local immune response alterations, did not affect the ability of non-immunodepressed rats to clear $P$. carinii organisms from their lungs (Fig. 2). Present results suggest therefore that $P$. carinii development depends rather on a deep depression of the immune response than on the alteration of pulmonary surfactant composition. They suggest also that the early perturbation of surfactant properties induced by Pneumocystis organisms that we reported previously (Escamilla et al., 1992, 1993; Aliouat et al., 1998; Prévost et al., 1998; Dei-Cas, 2000), is not enough, in absence of immunodepression, to allow the active Pneumocystis proliferation associated with $\mathrm{PcP}$.

Most likely, the main finding of the present work was the decrease of lung surfactant proteins (SP-A and SP-
D) involved in local defence. Thus, hypobaric-hypoxia conditions, though they were not enough to allow Pneumocystis proliferation, weakened nevertheless the lung defence mechanisms. Thus, blood lymphocytes of rats exposed to hypobaric-hypoxia conditions were more susceptible to oxidative stress than those of rats maintained in normobaric normoxic conditions (group 6) (Fig. 4). Paradoxically, surfactant proteins potentially involved in defence mechanisms were found to be increased in dexamethasone-treated rats of group 1 (maintained in normobaric normoxic conditions), which developed PcP. This finding was consistent with previous observations of a drastic increase of SP-A induced by Pneumocystis (Atochina et al., 2001; Schmidt et al., 2006).

Anyway, on the bottom, the basic question of what is the role of SP-A and SP-D in Pneumocystis infections remains to be answered. Other experimental models were used to address this question. In a transgenic SPD-overexpression mouse model, which developed PCP after antibody-induced $\mathrm{CD}^{+}$-cell depletion and inoculation of P. murina Keely et al. 2004, it was observed that both $P$. murina infection and lung inflammatory changes were increased (Vuk-Pavlovic et al., 2006). With regard with SP-A, in the pulmonary lavage fluid of SP-A deficient mice with corticosteroid-induced PCP were observed higher concentrations of TNF- $\alpha$, IFN- $\gamma$ and MIP-2 than in wild-type mice (Linke et al., 2005). The authors suggested that SP-A could exert a protective role against $P$. murina. But using the same model no difference in $P$. murina clearance was observed between SP-A deficient and wild-type mice after corticosteroid withdrawal (Linke et al., 2006). This observation is consistent with our present observations in rats infected with $P$. carinii.

In fact, Pneumocystis-related pulmonary surfactant changes, especially the early changes reported at the beginning of the infection (Escamilla et al., 1992, 1993; Aliouat et al., 1998) could result from lung inflammatory changes (Grubor et al., 2006) that precede the Pneumocystis infection. Actually, in corticosteroidtreated hosts or in hosts in which immunodepression resulted from other causes, e.g. HIV infection, congenital immunodepression syndromes, or in special situations like spontaneous PcP in rabbits (Allaert et al., 1996, 1997; Aliouat et al., 1998; Rajagopalan et al., 1998), the pulmonary surfactant composition is most likely altered before a noticeable proliferation of Pneumocystis organisms.

Both strong increase of SP-A associated with Pneumocystis infection (Phelps \& Rose, 1991; Atochina et al., 2001; Schmidt et al., 2006) and the apparent absence of influence of this protein on Pneumocystis clearance (Linke et al., 2006, and present results) suggest that SP-A might somewhat protect Pneumocystis organisms from host defence mechanisms. Although, 
alternatively, recent observations suggest that SP-A plays a role in the protection of the host against Pneumocystis infection (Atochina et al., 2004; Linke et al., 2005), in an earlier work Koziel et al. (1998) showed that increased levels of SP-A, through binding to the surface of $P$. carinii organisms, may interfere with alveolar macrophage recognition making phagocytosis more difficult. In the same way, though by a different mechanism, Yong et al. (2003) showed that SP-D dodecamers mediate optimal aggregation of $P$. carinii, which was shown to be responsible for the impaired phagocytosis of the organisms by alveolar macrophages. SP-D-mediated aggregation of $P$. carinii and SP-A binding to this organism (though available data are contradictory) may represent ways by which it avoids elimination by the host.

\section{ACKNOWLEDGEMENTS}

T This work was supported by European Union (FP5 'EUROCARINII' network, QLK2-CT-2000-01369), French Ministry of Research (EA3609), Spanish Ministry of Science and Technology (SAF2003-06061) and "Fondo de Investigacion Sanitaria" ("Instituto de Salud Carlos III, FIS Europeo 03/1743). This project was developed in the framework of the ANR-ERA-NET "Pneumocystis" PathoGenoMics Program (ANR-06-PATHO009-01). We would like to thank Dr A. Saoudi (Purpan Hospital, Toulouse) for providing generously the antibodies used to assess the rat immune function.

\section{REFERENCES}

Aliouat E.M., Escamilla R., Cariven C., Vieu C., Mullet C., DeiCAS E.. \& PRÉVOST M.C. Surfactant changes during experimental pneumocystosis are related to Pneumocystis development. European Respiratory Journal, 1998, 11, 542-547.

Aliouat E.M., Dei-Cas E., Ouaissi A., Palluault F., Soulez B. \& Camus D. In vitro attachment of Pneumocystis carinii from mouse and rat origin. Biology of the Cell, 1993, 77, 209-217.

Allaert A., Jounallt T., Rajagopalan-Levasseur P., Odberg-Ferragut C., Dei-Cas E. \& Camus D. Detection of cytokine mRNA in the lung during the spontaneous Pneumocystis carinii pneumonia of the young rabbit. Journal of Eukaryotic Microbiology, 1997, 44 (Suppl. 1), 45.

Allaert A., Rajagopalan-Levasseur P., Jouault T., Camus D. \& DeiCAS E. Role of alveolar macrophages during the spontaneous Pneumocystis carinii pneumonia of rabbit at weaning. Journal of Eukaryotic Microbiology, 1996, 43 (Suppl. 1), 23.

Ambrose H.E., Keely S.P., Aliouat E.M., Dei-Cas E., Wakefield A.E., Miller R.F. \& Stringer J. Expression and complexity of the PRT1 multigene family of Pneumocystis carinii. Microbiology, 2004, 150, 293-300.

Anonyme. In vitro systems in Pneumocystis research. Parasitology Today 1996, 12, 245-249.
Atochina E.N., Beck J.M., Preston A.M., Haczku A., Tomer Y., SCanlon S.T. Fusaro T., Casey J., Hawgood S., Gow A.J. \& BEERS M.F. Enhanced lung injury and delayed clearance of Pneumocystis carinii in surfactant protein A-deficient mice: attenuation of cytokine responses and reactive oxygennitrogen species. Infection and Immunity, 2004, 72, 60026011.

Atochina E.N., Beck J.M., Scanlon S.T., Preston A.M. \& Beers M.F. Pneumocystis carinii pneumonia alters expression and distribution of lung collectins SP-A and SP-D. Journal of Laboratory and Clinical Medicine, 2001, 137, 429-439.

Atochina E.N., Beers M.F., Scanlon S.T., Preston A.M. \& Beck J.M. P. carinii induces selective alterations in component expression and biophysical activity of lung surfactant. American Journal of Physiology. Lung cellular and molecular physiology, 2000, 278, L599-L609.

Augusto L., Le Blay K., Auger G., Blanot D. \& Chaby R. Interaction of bacterial lipopolysaccharide with mouse surfactant protein C inserted into lipid vesicles. American Journal of Physiology. Lung cellular and molecular physiology, 2001, 281, L776-L785.

Augusto L.A., Li J., Synguelakis M., Johansson J. \& Chaby R. Structural basis for interactions between lung surfactant protein $\mathrm{C}$ and bacterial lipopolysaccharide. Journal of Biological Chemistry, 2002, 277, 23484-23492.

Barten M.J., Gummert J.F., van Gelder T., Shorthouse R. \& MORRIS R.E. Flow cytometric quantitation of calcium-dependent and -independent mitogen-stimulation of $\mathrm{T}$ cell functions in whole blood: inhibition by immunosuppressive drugs in vitro. Journal of Immunological Methods, 2001, 253, 95-112.

Beers M.F., Atochina E.N., Preston A.M. \& Beck J.M. Inhibition of lung surfactant protein B expression during Pneumocystis carinii pneumonia in mice. Journal of Laboratory and Clinical Medicine, 1999, 133, 423-433.

Beers M.F. \& Mulugeta S. Surfactant protein C biosynthesis and its emerging role in conformational lung disease. Annual Review of Physiology, 2005, 67, 663-696.

BRADFORD M.M. A rapid and sensitive method for the quantitation of microgram quantities of protein utilizing the principle of protein-dye binding. Analytical Biochemistry, 1976, 72, 248254.

Calderon E.J., Regordan C., Medrano F.J., Ollero M. \& Varela J.M. Pneumocystis carinii infection in patients with chronic bronchial disease. Lancet, 1996, 347, 977.

Cano S., Capote F., Pereira A., Calderon E. \& Castillo J. Pneumocystis carinii pneumonia in patients without predisposing illnesses. Acute episode and follow-up of five cases. Chest, 1993, 104, 376-381.

Chabé M., Dei-Cas E., Creusy C., Fleurisse L., Respaldiza N., Camus D. \& Durand-Joly I. Immunocompetent hosts as a reservoir of Pneumocystis organisms: histological and rt-PCR data demonstrate active replication. European Journal of Clinical Microbiology and Infectious Diseases, 2004, 23, 89-97.

Chohan I.S., Singh I., Balakrishnan K. \& Talwar G.P. Immune response in human subjects at high altitude. International Journal of Biometeorology, 1975, 19, 137-143.

Coquette A., Vray B. \& Vanderpas J. Role of vitamin E in the protection of the resident macrophage membrane against oxidative damage. Archives Internationales de Physiologie et de Biochimie, 1986, 94, S29-S34.

Crouch E.C. Surfactant protein-D and pulmonary host defense. Respiratory Research, 2000, 1, 93-108. 
Crouch E. \& Wright J.R. Surfactant proteins a and d and pulmonary host defense. Annual Review of Physiology, 2001, 63, 521-554.

DeI-Cas E. Pneumocystis infections: the iceberg? Medical Mycology, 2000, 38 (Suppl. 1), 23-32.

Dei-Cas E., Brun-Pascaud M., Bille-Hansen V., Allaert A. \& Aliouat E.M. Animal models of pneumocystosis. FEMS Immunology and Medical Microbiology, 1998, 22, 163-168.

Dei-Cas E., Chabé M., Moukhlis R., Durand-Joly I., Aliouat E.M., Stringer J.R., Cushion M.T., Noel C., Sybren de Hoog G., Guillot J. \& Viscogliosi E. Pneumocystis oryctolagi sp. nov., an uncultured fungus causing pneumonia in rabbits at weaning: review of current knowledge, and description of a new taxon on genotypic, phylogenetic and phenotypic bases. FEMS Microbiology Reviews, 2006, 80, 853-871.

Dhainaut J.F., Charpentier J. \& Chiche J.D. Transforming growth factor- $\beta$ : a mediator of cell regulation in acute respiratory distress syndrome. Critical Care Medicine, 2003, 31, S258-S264.

Dobbs L.G., Mason R.J., Williams M.C., Benson B.J. \& Sueishi K. Secretion of surfactant by primary cultures of alveolar type II cells isolated from rats. Biochimica et Biophysica Acta, 1982, $713,118-127$.

Dumoulin A., Mazars E., Seguy N., Gargallo-Viola D., Vargas S., Cailliez J.C., Aliouat E.M. \& Dei-Cas E. Transmission of Pneumocystis carinii disease from immunocompetent contacts of infected hosts to susceptible hosts. European Journal of Clinical Microbiology and Infectious Diseases, 2000, 19, 671-678.

escamilla R., Prevost M.C., Cariven C., Hermant C., Krempf M. \& CHAP H. Bronchoalveolar lavage phospholipid abnormalities in HIV-infected patients. European Respiratory Journal 1993, 6, 1301-1307.

escamilla R., Prevost M.C., Hermant C., Caratero A., Cariven C. \& Krempr M. Surfactant analysis during Pneumocystis carinii pneumonia in HIV-infected patients. Chest, 1992, 101, 1558-1562.

Facco M., Zilli C., Siviero M., Ermolao A., Travain G., Baesso I., Bonamico S., Cabrelle A., Zaccaria M. \& Agostini C. Modulation of immune response by the acute and chronic exposure to high altitude. Medicine and Science in Sports and Exercise, 2005, 37, 768-774

Fisher J.H., McCormack F., Park S.S., Stelzner T., Shannon J.M. \& Hofmann T. In vivo regulation of surfactant proteins by glucocorticoids. American Journal of Respiratory Cell and Molecular Biology, 1991, 5, 63-70.

Frenkel J.K. Pneumocystis pneumonia, an immunodeficiencydependent disease (IDD): a critical historical overview. Journal of Eukaryotic Microbiology, 1999, 46 (Suppl. 1): 89-92.

Gigliotti F., Harmsen A.G. \& Wright T.W. Characterization of transmission of Pneumocystis carinii f. sp. muris through immunocompetent BALB/C mice. Infection and Immunity, 2003, 71, 3852-3856.

Glasser S.W., Burhans M.S., Korfhagen T.R., Na C.L., Sly P.D., Ross G.F., Ikegami M. \& Whitsett J.A. Altered stability of pulmonary surfactant in SP-C-deficient mice. Proceedings of the National Academy of Sciences (USA), 2001, 98, 6366-6371.

Gortner L., Hilgendorff A., Bahner T., Ebsen M., Reiss I. \& RudLOFF S. Hypoxia-induced intrauterine growth retardation: effects on pulmonary development and surfactant protein transcription. Biology of the Neonate, 2005, 88, 129-135.

Grubor B., Meyerholz D.K. \& Ackermann M.R. Collectins and cationic antimicrobial peptides of the respiratory epithelia. Veterinary Pathology, 2006, 43, 595-612.
Guiol C., Montastruc P. \& Prevost M.C. Renal effect of acute hypobaric pressure breathing in normal and diabetes insipidus rats. Journal de Physiologie (Paris), 1986, 81, 41-44.

HaAgsman H.P. \& Diemel R.V. Surfactant-associated proteins: functions and structural variation. Comparative Biochemistry and Physiology. Part A, Molecular \& Integrative Physiology, 2001, 129, 91-108.

Hirche T.O., Crouch E.C., Espinola M., Brokelman T.J., Mecham R.P., DeSilva N., Cooley J, Remold-O’Donnell E. \& BelaAouj A. Neutrophil serine proteinases inactivate surfactant protein $\mathrm{D}$ by cleaving within a conserved subregion of the carbohydrate recognition domain. Journal of Biological Chemistry 2004, 279, 27688-27698.

Ingenito E.P., Mark L., Morris J., Espinosa F.F., Kamm R.D. \& JOHNSON M. Biophysical characterization and modeling of lung surfactant components. Journal of Applied Physiology, 1999, 86, 1702-1714.

JAIN M. \& SZNAJDER J.I. Effects of hypoxia on the alveolar epithelium. Proceedings of the American Thoracic Society, 2005, 2, 202-205.

Khubchandani K.R. \& SNYDER J.M. Surfactant protein A (SP-A): the alveolus and beyond. Faseb Journal 2001, 15, 59-69.

Kovacs J.A., Gill V.J., Meshnick S. \& Masur H. New insights into transmission, diagnosis, and drug treatment of Pneumocystis carinii pneumonia. Journal of the American Medical Association, 2001, 286, 2450-2460.

Koziel H., Phelps D.S., Fishman J.A., Armstrong M.Y., Richards F.F. \& Rose R.M. Surfactant protein-A reduces binding and phagocytosis of Pneumocystis carinii by human alveolar macrophages in vitro. American Journal of Respiratory Cell and Molecular Biology, 1998, 18, 834-843.

Kitaev M.I. \& Tokhtabaev A.G. T-and B-lymphocytes in adaptation to high altitude. Kosmicheskaia Biologiia $i$ Aviakosmicheskaia Meditsina, 1981, 15, 87-89.

Lesgards J.F., Lehucher-Michel M.P., Vidal N., Prost M. \& Stocker $\mathrm{P}$. Assessment of antioxidative activity of lipid- and watersoluble vitamins in human whole blood. Comparative analysis between a biological test and chemical methods. International Journal for Vitamin and Nutrition Research, 2005, 75, 11-18.

Linke M., Ashbaugh A., Koch J., Tanaka R. \& Walzer P.D. Surfactant protein A limits Pneumocystis murina infection in immunosuppressed $\mathrm{C} 3 \mathrm{H} / \mathrm{HeN}$ mice and modulates host response during infection. Microbes and Infection, 2005, 7, 748759 .

Linke M., Ashbaugh A., Koch J., Tanaka R. \& Walzer PD. Efficient resolution of Pneumocystis murina infection in surfactant protein A-deficient mice following withdrawal of corticosteroid-induced immunosuppression. Journal of Medical Microbiology, 2006, 55, 143-147.

Madjdpour C., Jewell U.R., Kneller S., Ziegler U., Schwendener R., Booy C., Klausli L., Pasch T., Schimmer R.C. \& BeckSCHIMmer B. Decreased alveolar oxygen induces lung inflammation. American Journal of Physiology. Lung cellular and molecular physiology, 2003, 284, L360-L367.

MEEHAN R.T. Immune suppression at high altitude. Annals of Emergency Medicine, 1987, 16, 974-979.

Melton K.R., Nesslein L.L., Ikegami M., Tichelaar J.W., Clark J.C., Whitsett J.A. \& WeAVER TE. SP-B deficiency causes respiratory failure in adult mice. American Journal of Physiology. Lung cellular and molecular physiology, 2003, 285, L543-L549. 
Meydani S.N., Wu D., Santos M.S. \& Hayek M.G. Antioxidants and immune response in aged persons: overview of present evidence. American Journal of Clinical Nutrition, 1995, 62, 1462S-1476S.

Miakotina O.L. \& SNYDER J.M. TNF- $\alpha$ inhibits SP-A gene expression in lung epithelial cells via p38 MAPK. American Journal of Physiology. Lung cellular and molecular physiology, 2002, 283, L418-L427.

Miller R.F., Ambrose H.E. \& Wakefield A.E. Pneumocystis carinii f. sp. hominis DNA in immunocompetent health care workers in contact with patients with $P$. carinii pneumonia. Journal of Clinical Microbiology, 2001, 39, 3877-3882.

Mirrakhimov M.M. \& Kitaev M.I. Problems and prospects in alpine immunology. Vestnik Akademii meditsinskikh nauk SSSR, 1979, 4, 64-69.

Nardo L., Zhao L., Green L., Possmayer F., Richardson B.S. \& BOCKING A.D. The effect of repeated umbilical cord occlusions on pulmonary surfactant protein mRNA levels in the ovine fetus. Journal of the Society for Gynecologic Investigation, 2005, 12, 510-517.

Nesslein L.L., Melton K.R., Ikegami M., Na C.L., Wert S.E., Rice W.R., Whitsett J.A. \& Weaver T.E. Partial SP-B deficiency perturbs lung function and causes air space abnormalities. American Journal of Physiology. Lung cellular and molecular physiology, 2005, 288, L1154-L1161.

Nogee L.M., Wispe J.R., Clark J.C., Weaver T.E. \& Whitsett J.A. Increased expression of pulmonary surfactant proteins in oxygen-exposed rats. American Journal of Respiratory Cell and Molecular Biology, 1991, 4, 102-107.

Oviedo J.M., Casals C. \& Perez-Gil J. Pulmonary surfactant protein SP-B is significantly more immunoreactive in anionic than in zwitterionic bilayers. FEBS Letters 2001, 494, 236-240.

Palaniyar N., Ikegami M., Korfhagen T., Whitsett J. \& McCorMACK F.X. Domains of surfactant protein A that affect protein oligomerization, lipid structure and surface tension. Comparative Biochemistry and Physiology. Part A, Molecular E Integrative Physiology, 2001, 129, 109-127.

Perez-Gil J. \& KeOugh K.M. Interfacial properties of surfactant proteins. Biochimica et Biophysica Acta, 1998, 1408, 203-217.

Phelps D.S. \& Rose R.M. Increased recovery of surfactant protein A in AIDS-related pneumonia. American Review of Respiratory Disease, 1991, 143, 1072-1075.

Possmayer F. A proposed nomenclature for pulmonary surfactant-associated proteins. American Review of Respiratory Disease, 1988, 138, 990-998.

Prévost M.C., Escamilla R., Aliouat E.M., Cere N., Coudert P. \& Dei-Cas E. Pneumocystosis pathophysiology. FEMS Immunology and Medical Microbiology, 1998, 22, 123-128.

Prévost M.C., Vieu C. \& Douste-Blazy L. Hypobaric hypoxia on pulmonary wash fluid of rats. Respiration, 1980, 40, 76-80.

PryHuber G.S., KHALAK R. \& ZHAO Q. Regulation of surfactant proteins $\mathrm{A}$ and B by TNF- $\alpha$ and phorbol ester independent of NF-к B. American Journal of Physiology, 1998, 274, L289-L295.

Rajagopalan-Levasseur P., Allaert A., Dridba M., Odberg-Ferragut C., Jounult T., Creusy C., Camus D. \& Dei-Cas E. Response to Pneumocystis infection in an immunocompetent host. FEMS Immunology and Medical Microbiology, 1998, 22, 107-121.

Robertson B., van Golde L.M.G. \& Batenburg J.J. The pulmonary surfactant from molecular biology to clinical practice. Elsevier, Amsterdam, 1992.
SaiRam M., Sharma S.K., Dipti P., Pauline T., Kain A.K., Mongia S.S., Bansal A., Patra B.D., Ilavazhagan G., Devendra K. \& SelVAMURTHY W. Effect of hypobaric hypoxia on immune function in albino rats. International Journal of Biometeorology, 1998, 42, 55-59.

Schmidt R., Markart P., Ruppert C., Temmesfeld B., Nass R., LohMeyer J., SEeger W. \& Gunther A. Pulmonary surfactant in patients with Pneumocystis pneumonia and acquired immunodeficiency syndrome. Critical Care Medicine, 2006, 34, 2370-2376.

Sepkowitz K., Schluger N., Godwin T., Armstrong D., Cerami A. \& BuCALA R. DNA amplification in experimental pneumocystosis: characterization of serum Pneumocystis carinii DNA and potential P. carinii carrier states. Journal of Infectious Diseases, 1993, 168, 421-426.

Sing A., Roggenkamp A., Autenrieth I.B. \& Heesemann J. Pneumocystis carinii carriage in immunocompetent patients with primary pulmonary disorders as detected by single or nested PCR. Journal of Clinical Microbiology, 1999a, 37, 3409-3410.

Sing A., Wonhas C., Bader L., Luther M. \& Heesemann J. Detection of Pneumocystis carinii DNA in the air filter of a ventilated patient with AIDS. Clinical Infectious Diseases, 1999b, 29, 952-953.

Stocker P., Lesgards J.F., Vidal N., Chalier F. \& Prost M. ESR study of a biological assay on whole blood: antioxidant efficiency of various vitamins. Biochimica Biophysica Acta, 2003, 1621, 1-8.

Stringer J.R., Beard C.B., Miller R.F. \& Wakefield A.E. A new name (Pneumocystis jiroveci) for Pneumocystis from humans. Emergent Infectious Diseases, 2002, 8, 891-896.

Tokieda K., Ikegami M., Wert S.E., Batz J.E., Zou Y. \& WhitSETT J.A. Surfactant protein B corrects oxygen-induced pulmonary dysfunction in heterozygous surfactant protein B-deficient mice. Pediatric Research, 1999, 46, 708-714.

TRAPani I.L. Altitude, temperature and the immune response. Federation Proceedings, 1966, 25, 1254-1259.

Vuk-Pavlovic Z., Mo E.K., Icenhour C.R., Standing J.E., Fisher J.H. \& Limper A.H. Surfactant protein D enhances Pneumocystis infection in immune-suppressed mice. American Journal of Physiology. Lung cellular and molecular physiology, 2006, 290, L442-L449.

Walther F.J., Hernandez-Juviel J.M., Mercado P.E., Gordon L.M. \& WARING A.J. Surfactant with SP-B and SP-C analogues improves lung function in surfactant-deficient rats. Biology of the Neonate, 2002, 82, 181-187.

Whitsett J.A., Nogee L.M., Weaver T.E. \& Horowitz A.D. Human surfactant protein B: structure, function, regulation, and genetic disease. Physiological Reviews, 1995, 75, 749-757.

WhitsetT J.A. \& WeAVER T.E. Hydrophobic surfactant proteins in lung function and disease. New England Journal of Medicine, 2002, 347, 2141-2148.

WRIGHT J.R. Immunoregulatory functions of surfactant proteins. Nature Reviews. Immunology, 2005, 5, 58-68.

Yong S.J., Vuk-Pavlovic Z., Standing J.E., Crouch E.C. \& Limper A.H. Surfactant protein D-mediated aggregation of Pneumocystis carinii impairs phagocytosis by alveolar macrophages. Infection and Immunity 2003, 71, 1662-1671.

Reçu le 23 juillet 2007 Accepté le 31 octobre 2007 